\title{
Marketing Aspects of Image Formation and Investment Attractiveness of Territories and Enterprises
}

Keywords: Investment attractiveness, marketing of territories, image of territories.

JEL Classification: E22, M31, O16.

Paper type: Research article.

\footnotetext{
${ }^{1}$ Department of Geography, Faculty of History and Geography, Poltava V.G. Korolenko National Pedagogical University, Poltava, Ukraine; E-mail: $\underline{\text { S_Sevchuk@online.ua }}$ ${ }^{2}$ Department of Economics, Entrepreneurship and Marketing, Educational and Scientific Institute of Finance, Economics and Management, National University "Yuri Kondratyuk Poltava Polytechnic”, Poltava, Ukraine; E-mail: victoriya.vd@gmail.com

${ }^{3}$ Department of Management, Private Higher Education Establishment "Academician Stepan Demianchuk International University of Economics and Humanities”, Rivne, Ukraine;

E-mail: natalia.pawluk77@gmail.com

${ }^{4}$ Department of Management, Faculty of Economics, Ivan Franko National University of Lviv, Lviv, Ukraine; E-mail: marianna.kokhan@gmail.com

${ }_{5}^{5}$ Department of Economics, Management and Administration, Kherson Polytechnic College of Odessa National Polytechnic University, Kherson, E-mail: tetianaksau@gmail.com
} 


\section{Introduction}

A positive image of the territory and a successful brand is a means of economic competition and a tool of struggle for recognition, a guarantee of attracting investment in the development of the country, region, city, growth of tourist flows, and development of local infrastructure (Vinogradova and Lashchenko, 2014). Marketing of territory is an activity that allows to develop a set of measures aimed at the most effective and profitable for the territory use of available resources in order to increase its competitiveness and improve its image in a systematic form, with the help of basic marketing technologies, tools and strategies (Tregubov, 2010).

Previously, territorial marketing strategies were characterized by a focus on government subsidies, a limited number of projects, complete lack of commercial experience from government officials and management, and the widespread use of traditional territorial development methods without finding alternatives; then they have undergone significant changes in the current period. The greatest influence on the formation of modern marketing strategies of the territory was made by globalization of the economy, world market competition and fewer restrictions by the authorities and management (Tregubov, 2010). Accordingly, the government and local authorities formulate development strategies, despite the high level of competition and globalization through the dynamic development of information and communication technologies. The local authorities should clearly define the plan of key competencies in strategies, based on the success factors of the territory and strengths. Core competencies can change, and strengths become unsuitable for capacity development because of digital transformation. The data specified require an investigation of modern marketing aspects of image formation and investment attractiveness of the territories.

\section{Literature Review}

Different scientists call the distinctive competencies, core or organizational competencies (Prahalad and Hamel, 1990), invisible assets (Itami and Roehl, 1987), specific competence (Pavitt, 1991), resource deployments (Hofer and Schendel, 1978). The strategic significance of core capabilities has been investigated for decades, starting with the Rumelt's (1974) research. He discovered that two of nine diversification strategies were built on an existing resource or skill and connected with the highest performance. Mitchell's (1989) research about industry-specific capabilities indicates that increased likelihood of the fact that a firm could exploit a new technology within that industry, has confirmed the early work. Therefore, some authors suggest that effective competition is based less on strategic leaps than on incremental innovation that exploits carefully developed capabilities (Hayes, 1985; Quinn, 1980; Setyawan et al., 2014; Rupeika-Apoga and Solovjova, 2016).

The core capabilities theory started developing in 1990. The theory is connected with competencies and resources theories and have received much attention lately in 
strategic management theory. It is important to compete on capabilities, and as well, to leverage the firm's core competence as opposed to the emphasis on positioning within as industry during the early and mid-1980s. Some writers have even announced the arrival of a new paradigm: the so-called resource-based perspective within strategic management.

The main empirical research is Dororthy Leonard-Barton "Core Capabilities and Core Rigidities: A Paradox in Managing New Product Development" (LeonardBarton, 1992). Firstly, while core capabilities are traditionally viewed as clusters of individual technical systems, skills, and management systems, these dimensions of capabilities are deeply rooted in values that are often overlooked but are viewed as a critical fourth dimension. Secondly, traditional core capabilities have a downside that impedes innovation, which is called core rigidity. Thus, project managers, developing new products and processes, are faced with a paradox: how to take advantage of core capabilities without encountering their dysfunctional downside. Such projects play an important role in emerging strategies, emphasizing the need for change and paving the way (Leonard-Barton, 1992).

Many scholars have developed characteristics of core capabilities from different perspectives (Sadovy et al., 2009; Zhegus et al., 2016), and these characteristics include value, heterogeneity, silence, derivation, and dynamics. An analysis of the scientific works of foreign researchers on the problem of sources and criteria of competitive advantages of the territory showed that the most effective strategy is the strategy of key success factors (key competences) of the territory, proposed by Prahalad and Hamel (1990). According to this strategy, it is crucial to formulate a set of key competences that influence the acquisition of competitive advantages by the territory for the success of urban communities in a globalized market economy.

Leading economist researchers (Lv and Yang, 2016; Prahalad and Hamel, 1990) define the category of "core competencies" as the basis for "intellectual leadership", anticipatory creation, retention and development of specific sources of sustainable competitive advantages of the territory:

$>$ skill competence (the ability of the territory to produce goods and services in the field of material production at the level of higher world standards);

$>$ knowledge competence (the ability of a territory to create and sell new knowledge, technologies and knowledge-intensive products and services);

$>$ communications competence (ability of the territory to create and sell services in the sphere of communication of material, information and financial flows);

$>$ competence for effective management of the territory as a single system (corporation) aimed at achieving the overall goals of the leading influence groups; cooperation competence (the ability to effectively identify and reconcile the interests of different groups of influence, strategic partners and formulate common goals and strategies for achieving them on this basis). 


\section{Data and Methods}

To study the competitive advantages of the territories of Ukraine, a comparative analysis of regional development strategies for the regions with the highest and lowest investment volume for the period 2010-2018 was chosen. A comparative analysis of direct investments out of regions and into regions of Ukraine for 20102018 was carried out. Based on panel data as of the end of 2018, according to the State statistics service of Ukraine (n./d.a), the average values of direct investment volumes out of the economics and into the economics of different regions of Ukraine, standard deviation, minimum and maximum values for indicators that reflect the state of investment attractiveness of regions are calculated.

\section{Results and Discussion}

Marketing of territories begins with an assessment of the state of available resources in Ukraine, determining the marketing potential. The main tool for strategic analysis is the SWOT analysis of the region, which makes it possible for state authorities to determine competitive advantages and opportunities to strengthen them in a systematic way. As a result, a set of measures is being developed for the most efficient and profitable use of resources.

It is possible to estimate the multiplicative effect of the image formation of the territories of Ukraine on the basis of the following indicators:

$>$ share of regions that have approved and are implementing regional development strategies and action plans for their implementation, developed with the participation of the public, \%;

$>$ net inflow of foreign direct investment (according to the balance of payments);

$>$ direct investment (equity) into the Ukrainian economy by region (20102018);

$>$ direct investments (joint stock capital) from Ukraine's regions in economy of the countries of the world (2010-2018).

In Ukraine, all regions provided development and implementation of regional development strategies, $100 \%$ of regions provided approval and implementation of the action plan for the implementation of the regional strategy (the first stage), but $84 \%$ implemented the regional strategy and action plan for the implementation of the regional strategy (the second stage) (Table 1). 
Table 1. Share of regions that have approved and are implementing regional development strategies and action plans for their implementation, developed with the participation of the public, $\%$

\begin{tabular}{|l|l|l|l|l|}
\hline \multicolumn{2}{|l|}{2015} & 2016 & 2017 & 2018 \\
\hline Share of approved and implementing regions: & $\begin{array}{l}88 \% \\
(22 \text { regions })\end{array}$ & $\begin{array}{l}100 \% \\
(25 \text { regions })\end{array}$ & $\begin{array}{l}100 \% \\
(25 \text { regions })\end{array}$ & $\begin{array}{l}100 \% \\
(25 \text { regions })\end{array}$ \\
\hline regional strategy & $\begin{array}{l}64 \% \\
(16 \text { regions })\end{array}$ & $\begin{array}{l}96 \% \\
(24 \text { regions })\end{array}$ & $\begin{array}{l}100 \% \\
(25 \text { regions })\end{array}$ & - \\
\hline $\begin{array}{l}\text { action plan for the implementation of } \\
\text { the regional strategy (the first stage) }\end{array}$ & $\begin{array}{l}4 \% \\
(1 \text { region })\end{array}$ & $\begin{array}{l}64 \% \\
\text { (16 regions) }\end{array}$ & $\begin{array}{l}84 \% \\
(21 \text { regions })\end{array}$ \\
\hline $\begin{array}{l}\text { regional strategy action plan for the } \\
\text { implementation of the regional } \\
\text { strategy (the second stage) }\end{array}$ & $0 \%$ & &
\end{tabular}

Source: State statistics service of Ukraine (n./d.b).

In accordance with the Sustainable Development Goals, Ukraine has set a target for 2020 - 10000 000, 00 USD USA (Table 2). It is evident that the investment inflow of Poland exceeds the investment inflow in 2015-2016 - five times, in 2017 - four times, in 2018 - seven times. This means significant differences in the investment attractiveness and image of the territories.

Table 2. Net inflow of foreign direct investments (according to balance of payments) in Ukraine and Poland in 2015-2018, mln USD USA

\begin{tabular}{|l|l|l|l|l|}
\hline & 2015 & 2016 & 2017 & 2018 \\
\hline Ukraine (State Statistics Service of Ukraine) & 3012 & 3268 & 2593 & 2360 \\
\hline Ukraine (World Bank) & 3050 & 3441 & 2827 & 2476 \\
\hline Poland & 15065 & 18321 & 11762 & 16697 \\
\hline
\end{tabular}

Source: State Statistics Service of Ukraine (n./d.c), The World Bank (2018).

The average growth of direct investment in the Ukrainian economy in 2010-2018 was $-1.33 \%$, and the smoothed growth rate was $-2.33 \%$. This indicates a deterioration in the image of the regions. The regional structure of investments in the economy of Ukraine indicates that Vinnytsia, Zhytomyr, Ivano-Frankivsk, Mykolaiv, Poltava, Cherkasy and Chernihiv regions are characterized by an increase in direct investment in their territories, and therefore this indicates the presence of competitive advantages of these regions. On average, in 2010, the volume of direct investment amounted to 969,3 million US dollars, while in 2018 - 640,9 million US dollars. The deviation from the average volume has decreased: in 2010 the deviation was 3450,7 million US dollars, in 2018 - 3338,1 million US dollars.

During the period 2010-2018, there was an increase in the outflow of direct investment from the regions of Ukraine to the economies of the world by $1,11 \%$ annually, and the smoothed growth was $1,12 \%$. The average value of investment from the regions was 398.5 million US dollars in 2010, in 2018 - 503,5 million US dollars. Based on a comparative analysis of the strengths of the regions of Ukraine, the main competitive advantages are highlighted (Table 3 ). 
Table 3. Competitive advantages of territories with the highest level of investment (according to 2014-2018 data)

\begin{tabular}{|c|c|}
\hline $\begin{array}{l}\mathrm{Re} \\
\text { gio } \\
\mathrm{n}\end{array}$ & Competitive advantages \\
\hline 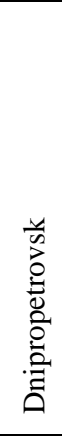 & $\begin{array}{l}\text { 1. Significant deposits of proved natural recourses. 2. Favorable weather and climate conditions } \\
\text { for the development of agriculture. } 3.90 \% \text { of the region's agricultural land is black earth type } \\
\text { soil. } 4 \text {. High level of economic development among all regions of Ukraine. 5. Developed } \\
\text { railway transport infrastructure, availability of river ports. 6. Developed foreign economic } \\
\text { relations. } 7 \text {. Developed financial infrastructure (banks, exchanges). 8. Scientific potential has } \\
\text { been preserved in various fields, especially in the fields of rocket science, metallurgy and } \\
\text { agriculture. 9. Large capacity of the regional consumer market in comparison with other } \\
\text { regions. 10. Sufficient labor resources of appropriate quality to meet the needs of employers in } \\
\text { the region. 11. An extensive network of higher education institutions that meets the needs of the } \\
\text { regional economy in training. 12. High level of urbanization. 13. An infrastructure has been } \\
\text { created to support investment attraction. 14. A training base has been created for training } \\
\text { specialists in the field of public administration and local self-government }\end{array}$ \\
\hline$\vec{\Delta}$ & $\begin{array}{l}\text { 1. Capital region of Ukraine. 2. Transit potential, developed transport infrastructure. } 3 \text {. } \\
\text { Availability of a wide network of water Fund lands. } 4 \text {. Sufficient provision of forest resources } \\
\text { for the needs of the population and production. } 5 \text {. Highly efficient labor market, the increase the } \\
\text { labour force. } 6 \text {. Active development of the youth and national-Patriotic movement. } 7 \text {. Leader in } \\
\text { housing construction in Ukraine. } 8 \text {. In terms of economic potential, the Kyiv region is one of the } \\
\text { five economically developed regions of Ukraine. 9. Powerful agro-industrial complex. } 10 \text {. } \\
\text { Availability of an extensive network of higher education and research institutions. 11. Kyiv } \\
\text { region belongs to the energy-saturated regions. 12. Investment-friendly region. 13. High level of } \\
\text { financial self-sufficiency of local budgets. 14. High level of entrepreneurial activity. } 15 \text {. } \\
\text { Reorientation of goods exports to the European market. 16. High availability of pre-school } \\
\text { education services. 17. Active implementation of health care reform. 18. Historical, cultural and } \\
\text { spiritual heritage. 19. Conditions have been created for the development of professional sports. } \\
\text { 20. Developed network of the centers of providing administrative services. }\end{array}$ \\
\hline $\begin{array}{l}\frac{\pi}{0} \\
\frac{\tilde{d}}{0}\end{array}$ & $\begin{array}{l}\text { 1. Advantageous geographical position. 2. Sufficiently developed and extensive infrastructure } \\
\text { with high capacity, availability of funds for the transportation of large-size and bulk cargo. } 3 \text {. } \\
\text { The existing tourist and recreational potential of the region. } 4 \text {. Favorable agro-climatic } \\
\text { conditions for the development of animal husbandry and cultivation of almost all agricultural } \\
\text { crops. 5. Developed network of protected areas. 6. Investment attractiveness of the region. } 7 \text {. } \\
\text { Further development of the food and processing industry. 8. Availability of large production } \\
\text { capacities for the production of mineral fertilizers. } 9 \text {. Growth in sales of wire and fiber products. } \\
10 \text {. Development of alternative sources of electric energy generation (SES, WES). } 11 \text {. } \\
\text { Availability of land plots with an area sufficient for the construction of SES. 12. Favorable } \\
\text { business environment for sustainable development of small and medium-sized businesses. } 13 \text {. } \\
\text { Significant cultural potential. 14. Unification of administrative services provided through the } \\
\text { CAA. 15. A telemedicine system has been created. 16. A network of dialysis centers has been } \\
\text { created. 17.Strong scientific support for the medical industry. }\end{array}$ \\
\hline
\end{tabular}

\section{Source: Own.}

A comparative analysis of the regions' competitive advantages of Ukraine with the highest investment volume indicates a number of strengths that ensure the investment attractiveness of the territories and serve as the main criteria for image formation. In contrast to investment-attractive regions, the regions of Ukraine with the lowest level of investment do not have certain competitive advantages. Strategies for the development of regions with low levels of investment attractiveness identify a number of challenges and problems that need to be addressed in different areas, 
and strong strategic sides do not provide sufficient for social-economic development of investment volume (Table 4).

Table 4. Competitive advantages of territories with a low level of investment (according to 2014-2018 data)

\begin{tabular}{|c|c|}
\hline $\begin{array}{l}\mathrm{Re} \\
\text { gio } \\
\mathrm{n}\end{array}$ & Competitive advantages \\
\hline 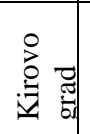 & $\begin{array}{l}\text { 1. Geographical location in the center of Ukraine. 2. The presence of a great number of mineral } \\
\text { deposits. 3. High level of fertility of Chernozem soils (the 4th place in Ukraine). }\end{array}$ \\
\hline $\begin{array}{l}\overline{\overline{0}} \\
\overline{0} \\
\stackrel{0}{0} \\
\sigma\end{array}$ & $\begin{array}{l}\text { 1. Advantageous geographical location. } 2 \text {. Favorable climate for farming. 3. Stable development } \\
\text { and relatively high productivity of the agricultural sector. } 4 \text {. Availability of raw materials for } \\
\text { further processing of agricultural products. } 5 \text {. The food industry with well-known brands is } \\
\text { developed. } 6 \text {. High potential of own raw materials for the construction industry. } 7 \text {. Availability of } \\
\text { production facilities in the machine-building and light industries. } 8 \text {. Availability of scientific and } \\
\text { technical base for personnel training. } 9 \text {. Availability of capacities for the production of biofuels } \\
\text { and bioethanol. } 10 \text {. Highly qualified workforce, high scientific potential. } 11 \text {. Availability of local } \\
\text { historical, cultural, and artistic brands. } 12 \text {. Most of the region's territories have a low level of } \\
\text { environmental load. } 13 \text {. Social-political stability, high spirituality of the population, one of the } \\
\text { lowest crime rates in Ukraine. }\end{array}$ \\
\hline 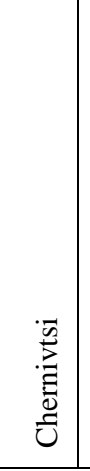 & $\begin{array}{l}\text { 1. Geographical location at the crossroads of the main roads of Central, southern and Eastern } \\
\text { Europe and the common border with European Union. 2. Positive dynamics of growth in the } \\
\text { volume of exports to European Union, which exceeds the average for Ukraine. 3. One of the best } \\
\text { areas in Ukraine for attracting international technical assistance (the 5th place). 4. Developed } \\
\text { research infrastructure, production and technical base in industry and agriculture. 5. Availability } \\
\text { of raw materials for the production of competitive products in the industry. 6. One of the highest } \\
\text { levels of development of small and medium-sized businesses in Ukraine. 7. Developed transport } \\
\text { infrastructure with significant transit potential, an airport with an international status. 8. High } \\
\text { efficiency of agricultural land use and favorable natural and climatic conditions for the } \\
\text { development of agricultural production, in particular the cultivation of fruit and vegetable } \\
\text { products. } 9 \text {. A significant number of objects of cultural heritage, natural reserve Fund to promote } \\
\text { the development of tourism. 10. Ecologically clean region (including mountain areas), low level } \\
\text { of emissions into the air: } 11 \text {. A developed education system, the available human resources. }\end{array}$ \\
\hline
\end{tabular}
Source: Own.

A comparative analysis of the competitive advantages of the Ukrainian regions made it possible to identify a number of differences: regions with a high level of investment attractiveness use available resources (land, water, economic, social); they are characterized by a high level of infrastructure development, economic development, developed agriculture, and production capacity. The existing potential for strategic development of competitive advantages is in regions with low investment volumes: raw material base, geographical location, export potential, transit potential, favorable conditions for agricultural development.

In contradiction from Ukraine, existing development strategies of voivodeships in Poland are implemented through voivodeship perspective programs. The strategies of the territories are aimed at creating conditions for the development of regions within the framework of the spatial approach, while in Ukraine the regions with a 
high level of investment attractiveness have already approved strategies in 2020 up till 2027, as well as the regions with a low level are at the development or approval stage. The image formation of territories in Poland, just as in Ukraine, is in accordance with the output characteristics of space (material, labor, financial resources). Therefore, the principle of sustainable development has been introduced in both countries.

The approaches to the image formation policy and investment attractiveness in Poland are covered in the "National Strategy for Regional Development 2010-2020: regions, cities, rural territories". In Poland, as contrasted with Ukraine, the principles of managing regional development processes and involving a wide range of partners have recently been established, which ensures increased participation of regional communities in decision-making. This practice is not prevailing in Ukraine precisely because of the low level of investment attractiveness.

The image of the territories and investment attractiveness in Poland is formed as a result of the regional policy for the development of territories, because the creation of economically strong innovative regions is set as a basic aim. The reorientation of development policy in Poland takes place through increasing the effectiveness of planning, developing links between the planning and operational levels, evaluating development programs, reducing the number of strategic documents. At the same time, there is no effective planning, prearranged and operational links, monitoring of territorial development programs in Ukraine (Ministerstwo Rozwoju, 2017).

Poland implements a new integrated development policy model based on (Ministerstwo Rozwoju, 2017):

1. Cooperation, as a multi-level system of government.

2. Coordination of the management process.

3. Territorial oriented approach (approach based on local conditions) - focus on investment combinations.

4. An integrated territorial approach - an emphasis on development-promoting measures.

5. Development of territorial potential.

6. Competitiveness - a result-oriented policy, a budget for improving efficiency.

7. An inclusive approach and shared responsibility.

In contradiction from Poland, Ukraine's regional policy is significantly different, taking into account first of all the decentralization processes that began in 2014 (in Poland in 1990). Accordingly, the image and level of investment attractiveness are characterized by a gap between countries.

As contrasted with Ukraine, Poland carefully selects regions for investment. The investor has off-limits to territories with access to intermodal logistics hubs in any of 
the 16 voivodeships, providing effective communication with other countries. The investor has the opportunity to cooperate with regional business partners, educational partners in each region, taking into account technology parks and industrial clusters. It is advisable to highlight the key competitive advantages of individual territories of Poland for more detailed analysis (Table 5).

Table 5. Competitive advantages of the Polish territories with the highest level of investment

\begin{tabular}{|c|c|}
\hline Region & Competitive advantages \\
\hline $\begin{array}{l}\text { Lower } \\
\text { Silesia }\end{array}$ & $\begin{array}{l}\text { 1. Favorable geographical location (German and Czech borders). 2. Highly developed } \\
\text { infrastructure. 4. Human resources. 5. Leader of economic growth and investment } \\
\text { attractiveness thanks to high quality of life. 6. Innovation Center. } 7 \text {. Transnational } \\
\text { corporations. 8. Wide range of business services. 9. Programs for expansion of business and } \\
\text { transport infrastructure and academic potential. 10. Functioning of } 4 \text { economic zones in the } \\
\text { field of mechanical engineering, household appliances, plastics production and FMCG. }\end{array}$ \\
\hline $\begin{array}{l}\text { Podkarpac } \\
\text { kie } \\
\text { Voivodesh } \\
\text { ip }\end{array}$ & $\begin{array}{l}\text { 1. Developed infrastructure. 2. The world-famous cluster "Aviation Valley". 3. Innovation } \\
\text { Center. 4. Developed aerospace industry. } 5 \text {. Functioning of economic zones. 6. Developed } \\
\text { automotive, metalworking, plastics production. } 7 \text {. Academic Center. 8. Favorable rules of } \\
\text { running business. }\end{array}$ \\
\hline $\begin{array}{l}\text { Kuyavian- } \\
\text { Pomerania } \\
\text { n } \\
\text { Voivodesh } \\
\text { ip }\end{array}$ & $\begin{array}{l}\text { 1. Location along beneficial transport routes. 2. International connections due to the airport. } \\
\text { 3. Developed chemical and pharmaceutical industry. } 4 \text {. Developed business services. 5. A } \\
\text { special economic zone is in effect. } 6 \text {. An attractive investment region for local and foreign } \\
\text { investors. 7. Academic cities. } 8 \text {. Key national cluster. }\end{array}$ \\
\hline
\end{tabular}

Source: Poland Investment and Trade Agency (2020)

The competitive advantages of the territories of Poland, which provide a high level of investment attractiveness, are integrated and generally based on the developed infrastructure (digital, business, transport), high-tech industries, advanced business services, economic zones, academic centers. These particular competitive advantages, combined with transparent business conditions, have created the image of highly profitable regions for investment. Integration of the competitive advantages of the Polish regions ensures the inflow of local and international investors and the development of activities of transnational corporations.

\section{Conclusion}

The conducted research makes it possible to identify several basic features of image formation and investment attractiveness of territories:

1) Unimproved potential of the territories leads to a decrease in the level of investment and a deterioration of the image of the regions. According to the analysis of the competitive advantages of Ukraine's territories, regions with high level of investment in their territories are characterized by developed competitive advantages with significant potential, whereas in regions with low investment volume, high unrealized potential leads to significant differences in competitive advantage. 
2) Comparative analysis of the competitive advantages of Ukraine's regions with the highest volume of investments shows a number of strengths that ensure the investment attractiveness of the territories and serve as the main criteria for image formation. As contrasted with the attractive investment regions, there is a lack of certain competitive advantages in the regions of Ukraine with the lowest level of investment. Strategies for the development of regions with low levels of investment attractiveness identify a number of challenges and issues that need to be addressed in different areas, and strong strategic parties do not provide sufficient investment volume necessary for social-economic development.

3) The analysis of the competitive advantages of Poland's territories reveals the synergy of decentralization and cooperation, which ensures the integration of competitive advantages and the utilization of the territories' potential, available human and material resources. As a result, competitive advantages, combined with transparent business conditions, have helped to shape the image of high-yielding regions for investment.

4) The competence to integrate the existing competitive advantages of the territory is traced in Poland, while in Ukraine the lack of this competence leads to the under-utilization of the potential of the regions. Accordingly, the regions of countries differ significantly in image and level of investment attractiveness. A territorial-oriented approach is being introduced in Poland (an approach taking into account local conditions), which implies an emphasis on a combination of investments and an integrated territorial approach, providing for an emphasis on activities that contribute to development. There is no such practice in Ukraine.

\section{References:}

Hayes, R.H. 1985. Strategic planning-forward in reverse? Harvard Business Review, 11, 111-119.

Hofer, C.W., Schendel, D. 1978. Strategy Formulation: Analytical Concepts. West Publishing, St. Paul, MN.

Itami, H., Roehl, T. 1987. Mobilizing Invisible Assets. Harvard University Press, Cambridge, MA.

Leonard-Barton, D. 1992. Core Capabilities and Core Rigidities: A Paradox in Managing New Product Development. Strategic Management Journal, 13, 111-125.

Lv, F., Yang, Y. 2016. An Extension Method of Identifying Core Capabilities of Serviceoriented Manufacturing Enterprises. Technical Journal of the Faculty of Engineering, 39(1), 313-319. https://doi.org/10.21311/001.39.1.34.

Ministerstwo Rozwoju. 2017. Decentralization and multi-level governance in Poland Ensure coherence of national and regional development strategies/policies. Available at https://www.oecd.org/regional/regional-policy/Децентралізація-та-багаторівневеуправління-у-Польщі.pdf

Mitchell, W. 1989. Whether and when? Probability and timing of incumbents' entry into emerging industrial subfields. Administrative Science Quarterly, 34, 208-230.

Pavitt, K. 1991. Key characteristics of the large innovating firm. British Journal of Management, 2, 41-50.

Poland Investment and Trade Agency. 2020. Poland, Land of Opportunities Electromobility and other sectors in the heart of Europe. Available at 
https://docplayer.net/152235294-Poland-land-of-opportunities-electromobility-andother-sectors-in-the-heart-of-europe.html.

Prahalad, C.K., Hamel, G. 1990. The core competence of the corporation. Harvard Business Review, 68(3), 79-91.

Quinn, J.B. 1980. Strategies for Change: Logical Incrementalism. Richard D. Irwin, Homewood, IL.

Rumelt, R.P. 1974. Strategy, Structure and Economic Performance, Harvard Business School Press, Boston, MA.

Rupeika-Apoga, R., Solovjova, I. 2016. Profiles of SMEs as Borrowers: Case of Latvia. In: Contemporary Issues in Finance: Current Challenges from Across Europe. Emerald Insight, DOI: 10.1108/S1569-2016375920160000098005.

Sadovy, V.A., Mogylna, N.A., Omelyanenko, V.A. 2009. Image of the region as a factor of attraction of foreign and domestic investments. The mechanism of regulation of the economy, 3(2), 282-287.

Setyawan, A.A., Dharmmesta, S.B., Purwanto, M.B., Nugroho, S.S. 2014. Model of Relationship Marketing and Power Asymmetry in Indonesia Retail Industry. International Journal of Economics and Business Administration, 2(4), 108-127.

State Statistics Service of Ukraine. (n./d.a). Direct investment (equity) in the economy of Ukraine / from Ukraine: by countries of the world; EU countries; types of economic activity; by region (2010-2018). Available at http://www.ukrstat.gov.ua.

State Statistics Service of Ukraine. (n./d.b). Goal 11. Sustainable development of cities and communities. Available at http://www.ukrstat.gov.ua.

State Statistics Service of Ukraine. (n./d.c). Goal 17.1.2. Net foreign direct investment inflows (according to balance of payments). Available at http://www.ukrstat.gov.ua.

The World Bank. 2018. Foreign direct investment, net inflows (BoP, current US\$). Available at https://data.worldbank.org/indicator/BX.KLT.DINV.CD.WD?view=chart

Tregubov, O.S. 2010. Theoretical aspects of territory marketing. Bulletin of Khmelnitsky National University, 6(4), 128-131.

Vinogradova, N.L., Lashchenko, O.V. 2014. Formation of the image and brand of the territory as a factor of increasing its competitiveness. AMSU Bulletin. Series: Public Administration, 2(11), 132-139.

Zhegus, O.V., Mikhailova, M.V., Sayenko, T.O., Zvyagina, Y.V. 2016. EVENT-marketing as a tool for forming the image of the territory. Economic strategy and prospects for development of trade and services, 1, 177-187. 